\title{
Trichomegaly of the eyelashes induced by the epidermal growth factor receptor inhibitor cetuximab in the treatment of metastatic colorectal cancer
}

\author{
Leonor Vasconcelos Matos, ${ }^{\oplus 1}$ Ana Pissarra, ${ }^{\circledR}$ Mariana Malheiro, ${ }^{2}$ Ana Neto Plácido ${ }^{3}$
}

${ }^{1}$ Oncology, Hospital Sao Francisco Xavier, Lisboa, Portugal

${ }^{2}$ Medical Oncology, Hospital de São Francisco Xavier, Lisbon, Portugal

${ }^{3}$ Medical Oncology, Centro Hospitalar de Lisboa Ocidental Lisboa, Portugal

\section{Correspondence to}

Dr Leonor Vasconcelos Matos, analeonormatos9@gmail.com

Accepted 15 April 2019
Check for updates

(C) BMJ Publishing Group Limited 2019. No commercial re-use. See rights and permissions. Published by BMJ.

To cite: Matos LV, Pissarra $A$, Malheiro M, et al. BMJ Case Rep 2019;12:e228968 doi:10.1136/bcr-2018 228968

\section{DESCRIPTION}

Cetuximab is a chimeric monoclonal antibody (MoAb) that competitively binds and inhibits the epidermal growth factor receptor (EGFR). EGFR is constitutively expressed in normal tissues such as the epidermis and hair follicle epithelium but also in some tumours, including colon and rectum. ${ }^{1}$ Cetuximab proved to be effective in the treatment of metastatic colorectal cancer when tumours are RAS wild type for mutation in exons 2, 3 and 4 of the KRAS and NRAS genes. Skin toxicity is the most important side effect of this agent, with up to $80 \%$ incidence, $15 \%$ of which are reported as severe. ${ }^{2}$ The mechanism appears to be related to modulation of the EGFR signalling pathway in keratinocytes. Additionally, serum levels of CXCL8 appear to be important for individual EGFR inhibitor-induced toxicity. The release of cytokines and other mediators of inflammation leads to altered cell growth and differentiation. ${ }^{3}$ It presents most commonly as an acneiform rash in the face and trunk and appears to be a sign of response. Other skin and hair toxicities can occur, although less reported, especially in clinical trials. Trichomegaly is one of these adverse events, usually occurring after 2-5 months of treatment, not always preceded by rash. Although apparently harmless, it can lead to eyelid infections and corneal ulceration due to abnormal eyelash growth. Therefore, oncologists should be aware of this side effect to assure prevention of complications. Prior to initiating treatment, patients should be elucidated about toxicities. If trichomegaly arises, patient counselling regarding lid hygiene, with avoidance of eye rubbing, should be performed. Management consists of eyelash clipping every 2-4 weeks and referral to an ophthalmologist for correct advise and complications.

We report the case of a 45-year-old woman, diagnosed in November 2017 with adenocarcinoma of left colon. Complete staging revealed multiple pulmonary and liver metastasis, not feasible for resection. Baseline carcinoembryonic antigen was $311 \mathrm{ng} / \mathrm{mL}$. Genetic analysis of the tumour did not show mutations of KRAS and NRAS genes, predicting response to anti-EGFR agents. Furthermore, no mutations on exon 15 of the BRAF gene were documented. Based on patient's excellent performance status, stage IV disease at diagnosis and after agreement, she initiated in December 2017 first-line palliative chemotherapy with C-FOLFIRI (cetuximab $450 \mathrm{mg} / \mathrm{m}^{2}$ intravenous loading dose, followed by $250 \mathrm{mg} / \mathrm{m}^{2}$ subsequent cycles; irinotecan $180 \mathrm{mg} / \mathrm{m}^{2}$ intravenous, leucovorin $50 \mathrm{mg}$ intravenous, fluorouracil $400 \mathrm{mg} / \mathrm{m}^{2}$ intravenous, followed by $2400 \mathrm{mg} / \mathrm{m}^{2}$ infusion pump for 46 hours). The patient reported good tolerance to treatment, being of underline the appearance of eczematous rash in the face after five cycles, G1 (CTCAE-v4.0). She maintained C-FOLFIRI, with documented response. After 14 cycles, she went to the oncology clinics with an acute infection of the eyelids that was clinically diagnosed as a hordeolum. Concomitantly, she complained of abnormal growth of her eyelashes, which became lengthened and curly (figures 1 and 2) and described this issue as extremely troublesome and unpleasant. She reported that this change had arisen 3 weeks earlier and worsening. Since our patient was not receiving other trichomegaly-inducing

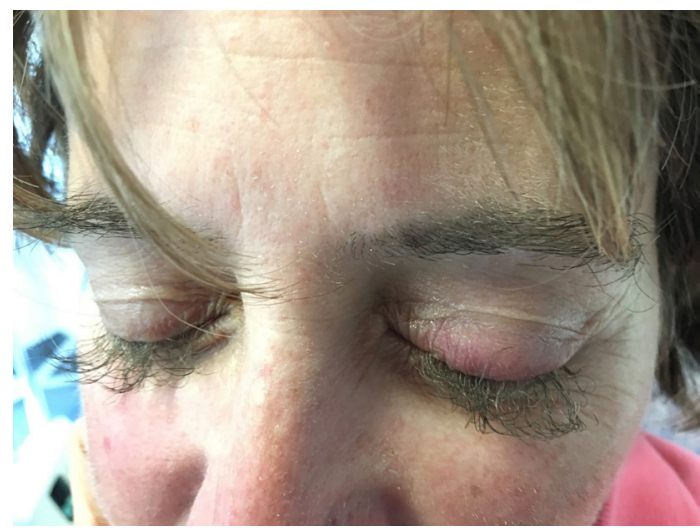

Figure 1 Trichomegaly of the eyelashes after treatment with cetuximab, $32 \mathrm{~mm}$ length.

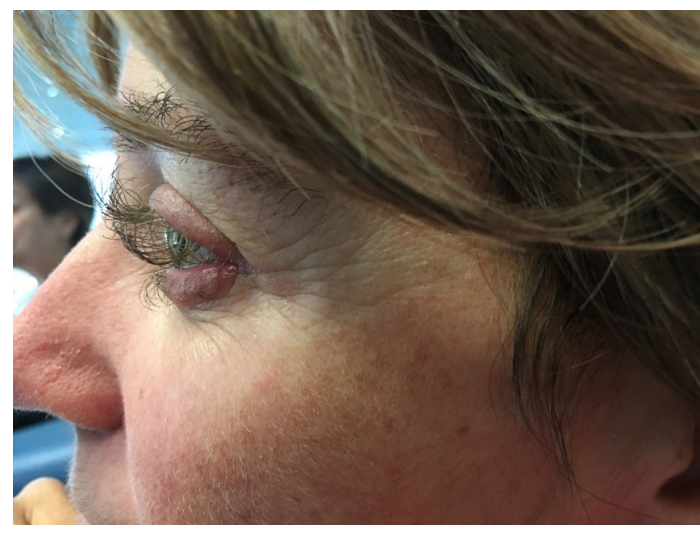

Figure 2 Trichomegaly of the eyelashes after treatment with cetuximab, profile. 
drugs, we have assigned this adverse event to the MoAb. After

\section{Patient's perspective}

People often come to me and say 'where have you made your eyelashes, they look so real'. This is the fun part. The not so fun part is the discomfort and itching that the long eyelids cause, and when you scratch with your hands, the more likely it is to make infections. And this is terrible. I totally agree that I should keep treatment, because it is helping me, but I just wish there was a more easy way to manage my 'beauty problem'.

\section{Learning points}

- Cetuximab is an antiepidermal growth factor receptor, with skin toxicity being the most frequent and remarkable one.

- Trichomegaly of the eyelashes is a rare and thus underreported side effect of cetuximab, appearing usually within 2-5 months of treatment.

- Understanding cutaneous side effects of epidermal growth factor receptor inhibitors, with correct management of complications and patient education and counselling, is important in order to improve quality of life. elucidating the patient about this effect and its cause, we've decided, with patient's agreement, to maintain treatment due to the excellent tumour response and good tolerability. After shortening of the eyelashes with the help of a beautician and advise on cleaning and management to avoid infections, the patient reported a marked improvement in her quality of life.

Contributors LVM had the most substantial contribution to the conception and design of the manuscript. LVM, AP, MM and ANP are the medical team responsible for the patient in question. LVM prepared the manuscript draft with important scientific contribution from author AP and MM. All authors approved the final manuscript.

Funding The authors have not declared a specific grant for this research from any funding agency in the public, commercial or not-for-profit sectors.

Competing interests None declared.

Patient consent for publication Obtained

Provenance and peer review Not commissioned; externally peer reviewed.

\section{REFERENCES}

1 Busam KJ, Capodieci P, Motzer R, et al. Cutaneous side-effects in cancer patients treated with the antiepidermal growth factor receptor antibody C225. Br J Dermatol 2001:144:1169-76.

2 European Medicines Agency, European Public Assessment Report, Erbitux product information. First Published 14/07/2009, Last Updated 19/07/2017. https://www.ema. europa.eu/documents/productinformation/erbitux-epar-product-information_en.pdf

3 Paul T, Schumann C, Rüdiger S, et al. Cytokine regulation by epidermal growth factor receptor inhibitors and epidermal growth factor receptor inhibitor associated skin toxicity in cancer patients. Eur J Cancer 2014;50:1855-63.

Copyright 2019 BMJ Publishing Group. All rights reserved. For permission to reuse any of this content visit https://www.bmj.com/company/products-services/rights-and-licensing/permissions/

BMJ Case Report Fellows may re-use this article for personal use and teaching without any further permission.

Become a Fellow of BMJ Case Reports today and you can:

- Submit as many cases as you like

- Enjoy fast sympathetic peer review and rapid publication of accepted articles

- Access all the published articles

Re-use any of the published material for personal use and teaching without further permission

For information on Institutional Fellowships contact consortiasales@bmjgroup.com

Visit casereports.bmj.com for more articles like this and to become a Fellow 